\title{
PENGEMBANGAN PERANGKAT PEMBELAJARAN MATEMATIKA BERBASIS KONTEKSTUAL DENGAN STRATEGI RELATING, EXPERIENCING, APPLYING, COOPERATING, TRANSFERING (REACT) PADA SISWA SEKOLAH DASAR
}

\section{DEVELOPMENT OF MATHEMATICAL CONTEXTUAL-BASED LEARNING TOOL WITH RELATING, EXPERIENCING, APPLYING, COOPERATING, TRANSFERING (REACT) STRATEGIES AT STUDENTS OF ELEMENTARY SCHOOL}

\author{
St. Nur Humairah Halim ${ }^{1}$, Muhammad Darwis ${ }^{2}$, Awi Dassa ${ }^{3}$ \\ ${ }^{1}$ Prodi Pend.Matematika FKIP Unismuh Makassar, \\ ${ }^{2,3}$ Prodi Pend.Matematika FMIPA UNM \\ Email: irahumairah08@gmail.com ${ }^{1}$, muhammaddarwis@gmail.com² ${ }^{2}$ awidassa@gmail.com ${ }^{3}$
}

\begin{abstract}
Abstrak
Penelitian ini merupakan penelitian pengembangan yang bertujuan untuk mengembangkan perangkat pembelajaran berbasis kontekstual dengan strategi relating, experiencing, applying, cooperating, transfering (REACT) pada siswa SD Inpres Karunrung Makassar dengan materi perbandingan dan skala yang meliputi buku siswa (BS), lembar kegiatan siswa (LKS), dan rencana pelaksanaan pembelajaran (RPP). Subjek penelitian ini adalah siswa kelas Va SD Inpres Karunrung Makassar yang berjumlah 26 orang. Prosedur pengembangan yang digunakan dalam penelitian ini adalah model 4D (define, design, develop, and disseminate). Hasil dari ujicoba terbatas menunjukkan bahwa perangkat pembelajaran yang dihasilkan telah bersifat praktis dan efektif. Hasil analisis data adalah siswa jadi lebih aktif dalam proses pembelajaran, guru dapat membimbing kelompok bekerja dan belajar, tingkat kemampuan guru dalam mengelola proses pembelajaran dengan menggunakan pendekatan kontekstual dan strategi REACT termasuk dalam kategori sangat tinggi, artinya penampilan guru dapat dipertahankan, skor rata-rata yang diperoleh siswa pada tes hasil belajar (THB) adalah 75,69 dari skor ideal 100 dengan standar deviasi 12,43, dimana 21 dari 26 siswa atau 80,77\% memenuhi ketuntasan individu yang menunjukkan bahwa ketuntasan klasikal tercapai dan pada umumnya siswa memberikan respon positif terhadap perangkat pembelajaran yang digunakan.
\end{abstract}

Kata Kunci: Pendekatan Pembelajaran Berbasis Kontekstual, Strategi REACT, Pengembangan Perangkat, Perbandingan dan Skala.

\begin{abstract}
This Research is research development (Research and Development) that aim to develop Tool of Mathematical Contextual-Based Learning with Relating, Experiencing, Applying, Cooperating, Transfering (REACT) strategies at Students of Inpres Karunrung Makassar Elementary School to the subject comparison and scale that includes student books, student activity sheets, and lesson plan execution. This subject research is student of class of Va class in Inpres Karunrung Makassar Elementary School with students amount as 26 people. Development procedures used in this study is a model or models 4D (Define, Design, Develop, and Disseminate). The results of the limited trial showed that the mathematics learning was effective and practical. Result of data analysis are student become more active in the learning process, the teacher can guide the group to work and learn, the level of teacher ability in
\end{abstract}


the lerning process by using contextual based learning with REACT strategy to a higher category, meaning that the teacher performance can be maintained, the average score obtained by students on achievement test is the ideal score of 75,69 from 100 with standard deviation 12,43, where 21 from 26 student or $80,77 \%$ of individuals who meet the exhaustiveness show that classical achieved, student responded positively to the learning device used generally.

Keywords: Contextual Based Learning Approach, REACT Strategy, Tool Development, Comparison and Scale.

\section{Pendahuluan}

Pendidikan merupakan faktor utama dalam pembentukan pribadi manusia. Namun, kendala yang dihadapi oleh dunia pendidikan tidak mudah. Banyak hal yang harus dibenahi dalam dunia pendidikan. Salah satu permasalahan yang dihadapi dalam pendidikan saat ini terkait terlaksananya proses belajar mengajar di sekolah adalah siswa dituntut agar dapat menghubungkan apa yang telah mereka pelajari dengan cara pemanfaatan pengetahuan tersebut pada saat ini dan kemudian hari dalam kehidupan siswa. Hal ini secara praktis akan menjadi tuntutan pula bagi guru sebagai pengajar dan pendidik agar dapat menuangkan sejumlah bahan pelajaran ke dalam otak siswa serta mampu membimbing dan membina siswa agar menjadi manusia susila yang cakap, aktif, kreatif, dan mandiri.

Permasalahan di atas hampir dialami oleh semua mata pelajaran baik dibidang sains maupun sosial, namun kendala yang paling banyak dihadapi ada pada mata pelajaran matematika, hal ini dapat dilihat dari peranan matematika yang sangat urgen di segala bidang. Salah satu kesulitan yang dialami siswa dalam mempelajari matematika di sekolah adalah tingkat keabstrakannya, hal ini menyebabkan rendahnya mutu keluaran/hasil pembelajaran yang ditandai dengan ketidakmampuan sebagian besar siswa menghubungkan apa yang telah mereka pelajari dengan cara pemanfaatan pengetahuan tersebut pada saat ini dan kemudian hari dalam kehidupan siswa. Oleh karena itu, perlu pembelajaran yang mampu mengaitkan antara materi yang diajarkan dengan dunia nyata siswa, di antaranya melalui penerapan pembelajaran berbasis kontekstual (Contextual Teaching and Learning/CTL).

Menurut Blanchard, Berns, dan Erickson (Kokom, 2010: 6) mengemukakan bahwa:

Contextual teaching and learning is conception of teaching and learning that helps teachers realate subject matter content to real world situations; and motivates students to make connections between knowledge and its applications to their lives as family members, citizens, and workers and engage in the hard work that learning requires.

Dengan demikian pembelajaran kontekstual merupakan konsep belajar dan mengajar yang membantu guru mengaitkan antara materi yang diajarkannya dengan situasi dunia nyata siswa dan mendorong siswa membuat hubungan antara pengetahuan yang dimilikinya dengan penerapannya dalam kehidupan mereka sebagai anggota keluarga, warga negara, dan pekerja.

Selanjutnya, Johnson (2007: 19) menggambarkan CTL sebagai berikut:

Contextual teaching and learning enables students to connect the content of academic subjects with immediate context of their daily lives, that is, with context of their personal, social, and cultural circumstance.

Kutipan di atas menegaskan hakikat CTL yang dapat diringkas dalam tiga kata, yaitu makna, bermakna, dan dibermaknakan. Hal ini berarti pembelajaran kontekstual 
memungkinkan siswa menghubungkan isi materi dengan konteks kehidupan sehari-hari untuk menemukan makna.

Namun, terlaksananya tujuan serta fungsi pembelajaran kontekstual tersebut tak akan lepas dari peran serta guru meskipun karakteristik dari kontekstual sendiri adalah berpusat pada siswa (student centered). Dalam hal ini, guru bertugas mengelola kelas sebagai sebuah tim yang bekerja bersama untuk menemukan pengetahuan dan keterampilan yang baru bagi siswa. Pengetahuan dan keterampilan diperoleh dengan menemukan sendiri bukan apa kata guru. Guru memberikan kesempatan kepada siswa untuk menemukan atau menerapkan sendiri ide-ide dan mengajak siswa agar dengan menyadari dan dengan sadar menggunakan strategi-strategi mereka sendiri untuk belajar.

Dari pemaparan di atas dapat disimpulkan bahwa guru lebih banyak berurusan dengan strategi daripada memberikan informasi kepada siswa. Kenyataannya, dari hasil wawancara dengan guru kelas Va di SD Inpres Karunrung Makassar diperoleh informasi bahwa yang berperan aktif dalam proses belajar mengajar masih didominasi oleh guru, siswa hanya mendengar dan mencatat apa yang diberikan tanpa aktif dalam proses belajar mengajar, bahkan ada yang tidak memperhatikan gurunya saat menjelaskan. Hal ini disebabkan tidak adanya variasi dalam proses pembelajaran.

Oleh karena itu, pemilihan strategi yang tepat dalam pelaksanaan pembelajaran kontekstual adalah sangat mutlak dilakukan oleh guru. Salah satu solusi yang ditawarkan untuk memberikan bantuan pemecahan masalah pemahaman konsep siswa adalah dengan menerapkan penggunaan strategi REACT dalam pembelajaran matematika. Karena strategi REACT merupakan strategi pembelajaran aktif yang menuntut siswa untuk terlibat dalam berbagai aktivitas belajar sehingga siswa tidak hanya menjadi objek pembelajaran, tetapi juga sebagai subjek yang dapat mengalami, menemukan, mengkonstruksikan, dan memahami konsep.

Trianto (2010: 109) menjelaskan bahwa kurikulum dan instruksi yang berdasarkan strategi pembelajaran kontekstual haruslah dirancang untuk merangsang 5 (lima) bentuk dasar dari pembelajaran yang terdiri dari relating, experiencing, applying, cooperating, dan transfering yang kemudian disingkat dengan REACT. Penjelasan masing-masing bentuk dasar pembelajaran kontekstual tersebut adalah sebagai berikut:

a. Relating (Menghubungkan)

Relating adalah belajar dalam suatu konteks sebuah pengalaman hidup yang nyata atau awal sebelum pengetahuan itu diperoleh siswa. Guru menggunakan relating ketika mereka mencoba menghubungkan konsep baru dengan sesuatu yang telah diketahui oleh siswa.

b. Experiencing (Mengalami)

Pada experiencing mungkin saja mereka tidak mempunyai pengalaman langsung berkenaan dengan konsep tersebut. Akan tetapi, pada bagian ini guru harus dapat memberikan kegiatan yang hands-on kepada siswa sehingga dari kegiatan yang dilakukan siswa tersebut, siswa dapat membangun pengetahuannya.

c. Applying (Mengaplikasikan)

Strategi applying sebagai belajar dengan menerapkan konsep-konsep. Kenyataannya, siswa mengaplikasi konsep-konsep ketika mereka berhubungan dengan aktivitas penyelesaian masalah yang hands-on dan proyek-proyek. 
d. Cooperating (Bekerja Sama)

Bekerja sama-belajar dalam konteks saling berbagi, merespon, dan berkomunikasi dengan pelajar lainnya adalah strategi instruksional yang utama dalam pengajaran kontekstual.

e. Transfering (Proses Transfer Ilmu)

Transfering adalah strategi mengajar yang kita definisikan sebagai menggunakan pengetahuan dalam sebuah konteks baru atau situasi baru suatu hal yang belum teratasi/diselesaikan dalam kelas.

Untuk mengimplementasikan pembelajaran matematika berbasis kontekstual dengan strategi REACT diperlukan perangkat yang sesuai dengan pendekatan tersebut. Mengingat pelaksanaan pembelajaran berbasis kontekstual dengan strategi REACT relatif baru di Indonesia sehingga perangkat pembelajaran yang dapat mendukung pelaksanaannya di kelas masih sangat terbatas.

Berdasarkan latar belakang di atas akan dilakukan penelitian dengan menerapkan sebuah strategi pembelajaran yang diperkirakan mampu mendukung upaya peningkatan kemampuan prestasi matematika siswa dengan berbasis kontekstual. Adapun tujuan penelitian ini adalah untuk menghasilkan perangkat pembelajaran matematika berbasis kontekstual dengan strategi REACT yang valid, praktis, dan efektif.

\section{Metode Penelitian}

Penelitian ini adalah penelitian pengembangan (research and development) yang bertujuan untuk mengembangkan perangkat pembelajaran matematika berbasis kontekstual dengan strategi REACT yang terdiri dari rencana pelaksanaan pembelajaran (RPP), lembar kegiatan siswa (LKS), dan buku siswa (BS) dengan menggunakan model pengembangan 4D. Ujicoba perangkat pembelajaran dalam penelitian ini dilaksanakan di SD Inpres Karunrung Makassar dan subjek penelitiannya adalah siswa kelas Va semester genap tahun ajaran 2011/2012 dengan jumlah siswa 26 orang.

Untuk memperoleh informasi tentang aktivitas siswa dan guru selama kegiatan pembelajaran matematika, pengelolaan guru dalam kegiatan belajar mengajar, tingkat penguasaan siswa terhadap materi yang telah diajarkan, dan respon siswa terhadap pembelajaran matematika maka instrumen-instrumen yang perlu dikembangkan adalah lembar pengamatan aktivitas siswa selama pembelajaran berlangsung, lembar pengamatan aktivitas guru selama pembelajaran berlangsung, lembar pengamatan pengelolaan pembelajaran matematika berbasis kontekstual dengan strategi REACT, tes penguasan siswa terhadap materi pelajaran, serta respon siswa terhadap perangkat dan kegiatan pembelajaran.

Data yang terkumpul tentang hasil pengamatan dan respon siswa dianalisis secara kualitatif. Data tentang hasil belajar di analisis secara kuantitatif dengan menggunakan statistik deskriptif yaitu skor rata-rata dan standar deviasi, median, frekuensi, persentase, nilai terendah dan nilai tertinggi yang dicapai siswa.

Desain pengembangan perangkat pembelajaran dengan ujicoba terbatas digambarkan dengan diagram alur sebagai berikut: 


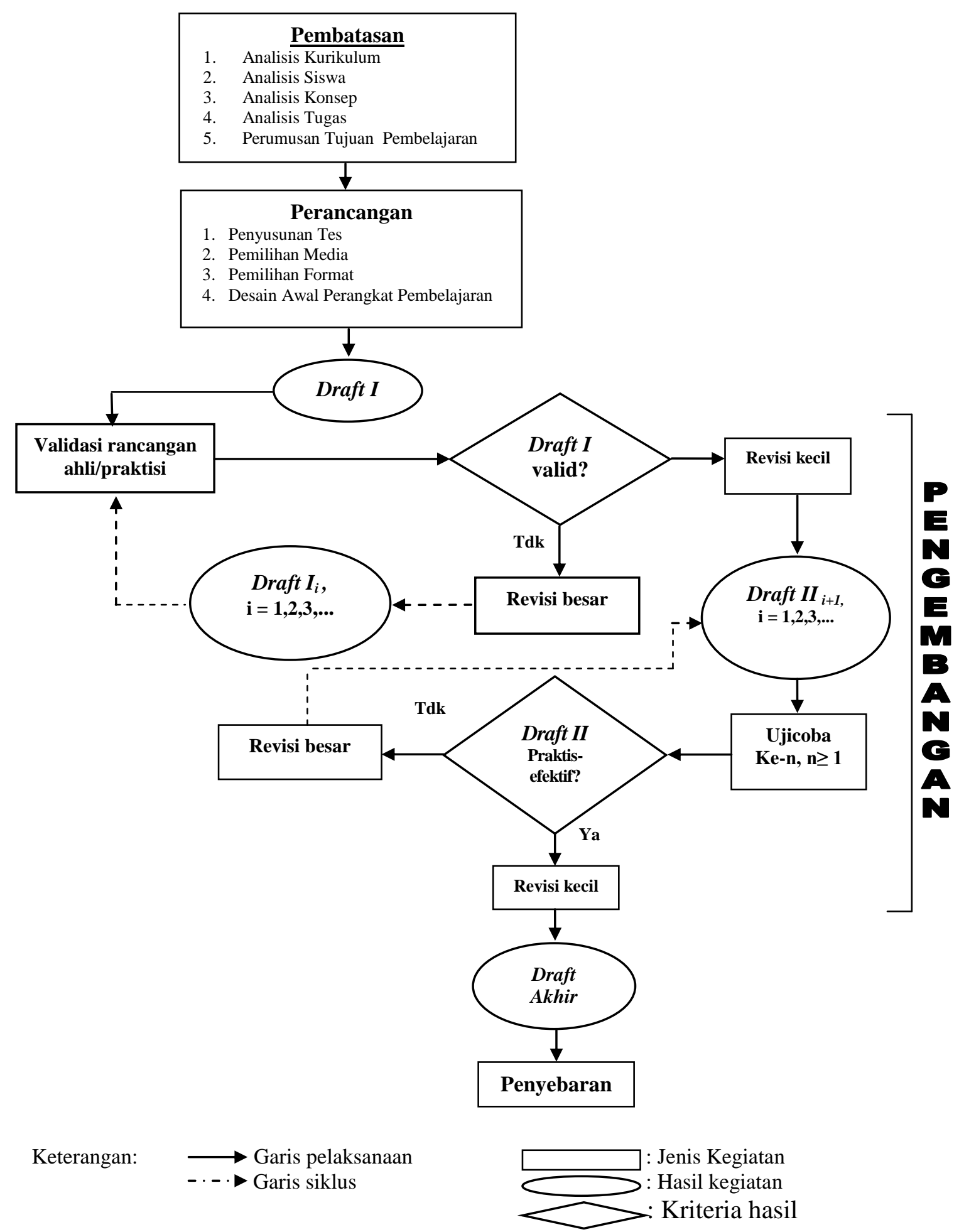

Gambar 1. Diagram modifikasi model pengembangan perangkat pembelajaran four- $D$ thiagarajan 


\section{Hasil dan Pembahasan}

\subsection{Hasil}

Berdasarkan hasil ujicoba perangkat pembelajaran matematika yang meliputi RPP, LKS, dan BS diperoleh data hasil pengamatan aktivitas siswa, data hasil pengamatan aktivitas guru, data hasil pengamatan pengelolaan pembelajaran berbasis kontekstual dengan strategi REACT, data hasil tes belajar siswa, dan respon siswa terhadap kegiatan. Data-data inilah yang digunakan untuk mengetahui keefektifan dan kepraktisan perangkat pembelajaran berbasis kontekstual dengan REACT. Hasil analisis masing-masing data sebagai berikut:

\subsubsection{Data Hasil Pengamatan Aktivitas Siswa}

Hasil pengamatan terhadap aktivitas siswa yang dilakukan oleh pengamat secara ringkas dapat dilihat pada tabel 1.

Tabel 1. Aktivitas Siswa Selama Kegiatan Pembelajaran

\begin{tabular}{|c|c|c|c|c|c|}
\hline \multirow[t]{3}{*}{ Kategori } & \multirow{2}{*}{\multicolumn{3}{|c|}{$\begin{array}{c}\text { Persentase Waktu Rata-rata } \\
\text { Jenis Aktivitas Guru } \\
\text { Pertemuan Ke- }\end{array}$}} & \multirow{3}{*}{$\begin{array}{l}\text { Rata- } \\
\text { rata } \\
(\%)\end{array}$} & \multirow{3}{*}{$\begin{array}{l}\text { Interval } \\
\text { Toleransi } \\
\text { PWI }(\%)\end{array}$} \\
\hline & & & & & \\
\hline & I & II & III & & \\
\hline $\begin{array}{l}\text { Memperhatikan } \\
\text { informasi dan mencatat } \\
\text { seperlunya }\end{array}$ & 11,11 & 12,22 & 13,33 & 12,22 & $6,1-16,1$ \\
\hline $\begin{array}{l}\text { Membaca LKS, materi } \\
\text { pembelajaran atau buku } \\
\text { siswa }\end{array}$ & 12,22 & 12,22 & 13,33 & 12,59 & $6,1-16,1$ \\
\hline Aktif terlibat dalam tugas & 25,56 & 24,44 & 20 & 23,33 & $17,2-27,2$ \\
\hline $\begin{array}{l}\text { Aktif berdiskusi dengan } \\
\text { teman }\end{array}$ & 15,56 & 17,78 & 18,89 & 17,41 & $12,8-22,9$ \\
\hline $\begin{array}{l}\text { Mencatat apa yang } \\
\text { disampaikan teman/guru }\end{array}$ & 11,11 & 12,22 & 12,22 & 11,85 & $3,9-13,9$ \\
\hline $\begin{array}{l}\text { Mengajukan pertanyaan } \\
\text { kepada teman/guru }\end{array}$ & 4,44 & 5,56 & 5,56 & 5,19 & $3,9-13,9$ \\
\hline $\begin{array}{l}\text { Menjawab/menanggapi } \\
\text { pertanyaan teman/guru }\end{array}$ & 10 & 6,67 & 7,78 & 8,15 & $3,9-13,9$ \\
\hline $\begin{array}{l}\text { Memberi bantuan } \\
\text { penjelasan kepada teman } \\
\text { yang membutuhkan }\end{array}$ & 4,44 & 5,56 & 6,67 & 5,56 & $6,1-16,1$ \\
\hline Kegiatan diluar tugas. & 5,56 & 3,33 & 2,22 & 3,70 & $0-5$ \\
\hline
\end{tabular}

Dari tabel 1, diketahui semua kategori aktivitas siswa yang diamati memenuhi Interval Toleransi PWI (\%) yang ditentukan. Artinya, kriteria pencapaian waktu ideal aktivitas siswa yang telah dibahas pada metode penelitian tercapai, yaitu 9 kategori terpenuhi dan secara otomatis syarat utama yaitu kategori (3), (4), (5), dan (8) terpenuhi.

\subsubsection{Data Hasil Pengamatan Aktivitas Guru}

Hasil pengamatan terhadap aktivitas guru yang dilakukan oleh pengamat secara ringkas dapat dilihat pada tabel 2. 
Tabel 2. Aktivitas Guru Selama Proses Pembelajaran

\begin{tabular}{|c|c|c|c|c|c|}
\hline \multirow[t]{3}{*}{ Kategori } & \multirow{2}{*}{\multicolumn{3}{|c|}{$\begin{array}{l}\text { Persentase Waktu } \\
\text { Rata-rata Jenis } \\
\text { Aktivitas Guru } \\
\text { Pertemuan Ke- } \\
\end{array}$}} & \multirow[t]{3}{*}{$\begin{array}{c}\text { Rata-rata } \\
(\%)\end{array}$} & \multirow[t]{3}{*}{$\begin{array}{l}\text { Interval } \\
\text { Toleransi } \\
\text { PWI }(\%)\end{array}$} \\
\hline & & & & & \\
\hline & $\mathrm{I}$ & II & III & & \\
\hline $\begin{array}{l}\text { Menginformasikan masalah yang } \\
\text { harus dikerjakan bersama }\end{array}$ & 13,33 & 6,67 & 6,67 & 8,89 & $6,1-16,1$ \\
\hline $\begin{array}{l}\text { Meminta siswa mengerjakan } \\
\text { tugas LKS kelompok dengan } \\
\text { kerjasama dalam kelompok }\end{array}$ & 6,67 & 13,33 & 6,67 & 8,89 & $6,1-16,1$ \\
\hline $\begin{array}{l}\text { Memberi arahan agar siswa } \\
\text { selalu berada dalam tugas } \\
\text { kelompok }\end{array}$ & 6,67 & 6,67 & 6,67 & 6,67 & $1,7-11,7$ \\
\hline $\begin{array}{l}\text { Mengontrol/berkeliling } \\
\text { memperhatikan kerja kelompok }\end{array}$ & 26,67 & 20 & 26,67 & 24,45 & $17,2-27,2$ \\
\hline $\begin{array}{l}\text { Membimbing/memberi bantuan } \\
\text { kepada siswa dalam aktivitas } \\
\text { kelompok }\end{array}$ & 26,67 & 26,67 & 26,67 & 26,67 & $21,7-31,7$ \\
\hline $\begin{array}{l}\text { Mengajukan pertanyaan yang } \\
\text { merangsang berfikir siswa } \\
\text { (pertanyaan yang membuka } \\
\text { wawasan) }\end{array}$ & 13,33 & 13,33 & 13,33 & 13,33 & $6,1-16,1$ \\
\hline Memberi umpan balik & 6,67 & 13,33 & 13,33 & 11,11 & $6,1-16,1$ \\
\hline Kegiatan di luar tugas & 0,00 & 0,00 & 0,00 & 0,00 & $0-5$ \\
\hline $\begin{array}{l}\text { Hasil pengamatan aktivit } \\
\text { aktivitas guru yang diamati men } \\
\text { Artinya, kriteria pencapaian wakt } \\
\text { penelitian tercapai, yaitu kategor } \\
\text { dengan kerjasama dalam kelon } \\
\text { kelompok, membimbing/member } \\
\text { mengajukan pertanyaan yang me }\end{array}$ & $\begin{array}{l}\text { guru } \\
\text { uhi } \\
\text { eal a } \\
\text { emin } \\
k \text {, n }\end{array}$ & $\begin{array}{l}\text { el } 2 \\
\text { val t } \\
\text { itas } \\
\text { iswa } \\
\text { ontro } \\
\text { epad }\end{array}$ & $\begin{array}{l}\text { ya } \\
\text { ng } \\
\text { erk }\end{array}$ & $\begin{array}{l}\text { bahwa } \\
\text { NI }(\%) \text { y } \\
\text { lah dibah } \\
\text { an tugas } \\
\text { g memp } \\
\text { lam aktiv }\end{array}$ & $\begin{array}{l}\text { lua kategori } \\
\text { ditentukan. } \\
\text { pada metode } \\
\text { S kelompok } \\
\text { atikan kerja } \\
\text { kelompok, }\end{array}$ \\
\hline
\end{tabular}

\subsubsection{Data Hasil Pengamatan Pengelolaan Pembelajaran Matematika}

Data hasil pengamatan pengelolaan pembelajaran matematika selama tiga kali pertemuan disajikan dalam tabel 3.

Tabel 3. Pengelolaan Pembelajaran yang Menggunakan Pendekatan Kontekstual dengan Strategi REACT

\begin{tabular}{|c|c|c|c|c|}
\hline \multirow[t]{2}{*}{ Aspek Pengamatan } & \multicolumn{3}{|c|}{ Pertemuan Ke- } & \multirow[t]{2}{*}{$\overline{K G}$} \\
\hline & 1 & 2 & 3 & \\
\hline \multicolumn{5}{|l|}{ I. Kegiatan Mengajar Belajar } \\
\hline \multicolumn{5}{|l|}{ A. Kegiatan Awal } \\
\hline \multicolumn{5}{|l|}{ Fase 1: Menyampaikan tujuan dan memotivasi siswa } \\
\hline $\begin{array}{l}\text { a. Guru memberi motivasi dan mempersiapkan siswa } \\
\text { sebelum memulai pelajaran. }\end{array}$ & 4 & 4 & 4 & 4 \\
\hline $\begin{array}{l}\text { b. Guru menyampaikan tujuan pembelajaran dan } \\
\text { menginformasikan model pembelajaran yang akan } \\
\text { dilakukan. }\end{array}$ & 4 & 3 & 4 & 3,67 \\
\hline
\end{tabular}




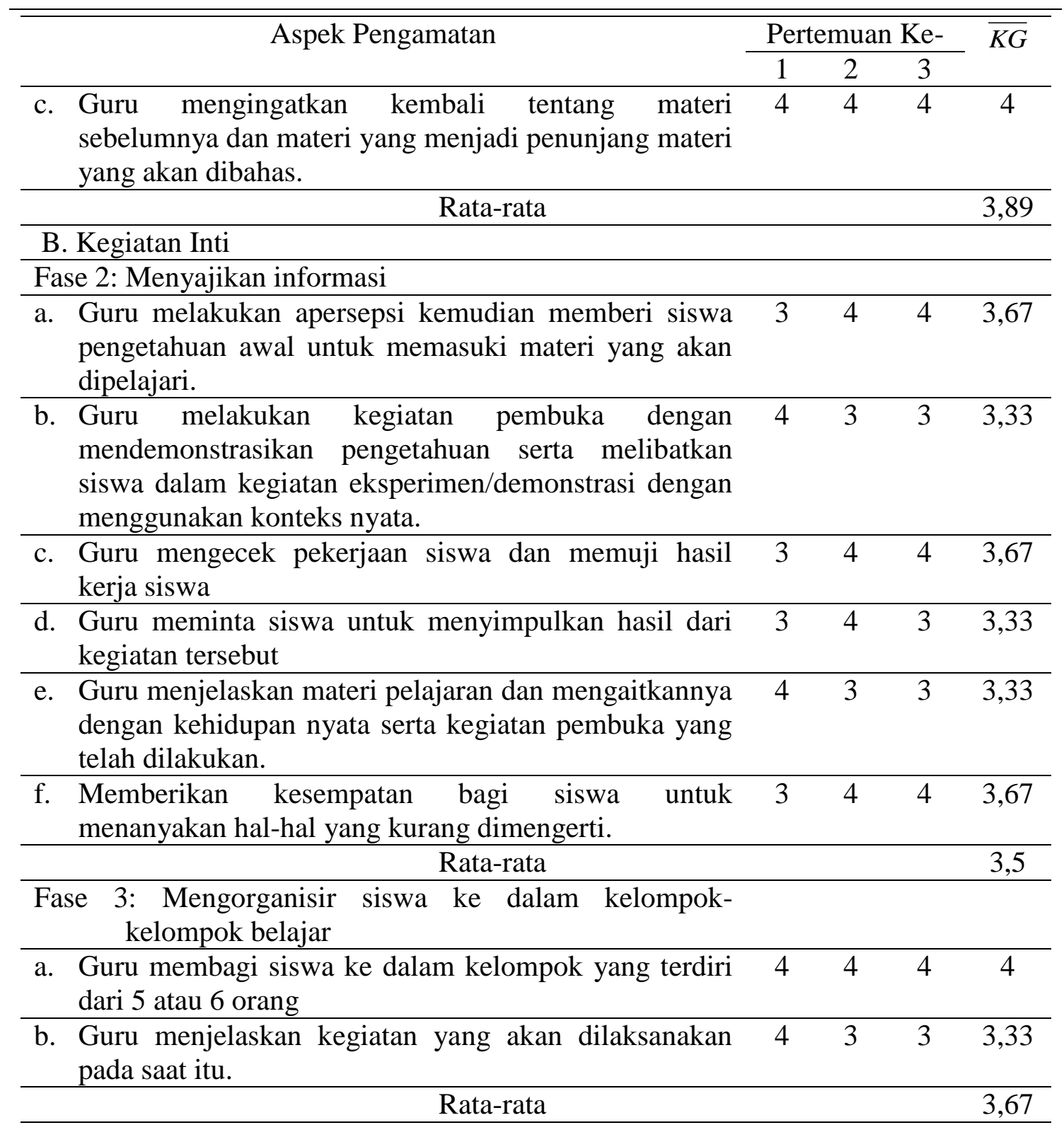

Fase 4: Membimbing kelompok bekerja dan belajar

a. Guru membimbing tiap-tiap kelompok dalam $3 \quad 3 \quad 3 \quad 3$ mengerjakan soal yang ada pada LKS dan meminta siswa untuk selalu berada dalam kelompok serta bekerja sama dengan yang lain.

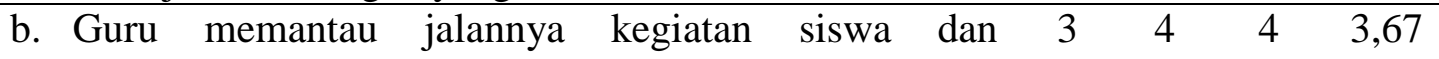
memberikan bantuan dan pengarahan secukupnya pada kelompok yang mengalami kesulitan.

c. Guru memperhatikan dengan seksama kerjasama $4 \quad 3 \quad 3 \quad 3,33$ kelompok dengan berkeliling kelas.

Rata-rata

Fase 5: Evaluasi

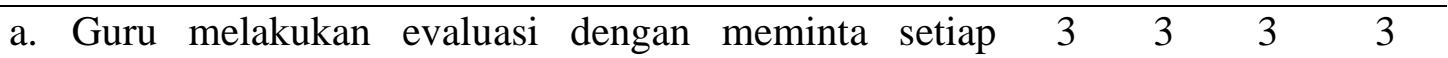
perwakilan kelompok mempresentasikan pekerjaannya dan memberikan kesempatan kepada kelompok lain 


\begin{tabular}{|c|c|c|c|c|}
\hline \multirow[t]{2}{*}{ Aspek Pengamatan } & \multicolumn{3}{|c|}{ Pertemuan $\mathrm{Ke}-$} & \multirow[t]{2}{*}{$\overline{K G}$} \\
\hline & 1 & 2 & 3 & \\
\hline \multicolumn{5}{|l|}{ untuk menanggapi. } \\
\hline $\begin{array}{l}\text { b. Guru memberikan kuis kemudian meminta beberapa } \\
\text { siswa untuk menjelaskan pekerjaannya kepada teman- } \\
\text { temannya }\end{array}$ & 3 & 4 & 3 & 3,33 \\
\hline Rata-rata & & & & 3,16 \\
\hline \multicolumn{5}{|l|}{ Fase 6: Memberikan penghargaan } \\
\hline $\begin{array}{l}\text { a. Guru memberikan penghargaan kepada seluruh siswa } \\
\text { atas partisipasi aktifnya dalam belajar }\end{array}$ & 4 & 4 & 3 & 3,67 \\
\hline $\begin{array}{l}\text { b. Guru merangkum butir-butir penting seluruh } \\
\text { pembelajaran dengan menanyakan kepada siswa apa } \\
\text { saja yang telah dipelajarinya }\end{array}$ & 4 & 4 & 3 & 3,67 \\
\hline
\end{tabular}

\begin{tabular}{llllr}
\hline & & & 3,67 \\
\hline C. Kegiatan Akhir & & & \\
\hline a. Guru memberikan tugas rumah kepada siswa & 3 & 4 & 4 & 3,67 \\
\hline b. Guru mengingatkan materi pada pertemuan berikutnya. & 3 & 4 & 4 & 3,67 \\
\hline & & & & 3,67
\end{tabular}

\begin{tabular}{|c|c|c|c|c|}
\hline II. Suasana Kelas & & & & \\
\hline 1. Siswa antusias & 3 & 4 & 3 & 3,33 \\
\hline 2. Guru antusias & 3 & 4 & 3 & 3,33 \\
\hline 3. Kegiatan sesuai alokasi waktu & 3 & 3 & 3 & 3 \\
\hline 4. Kegiatan sesuai skenario pada RPP. & 4 & 4 & 3 & 3,67 \\
\hline Rata-rata & & & & 3,33 \\
\hline Rata-rata Total & & & & 3,53 \\
\hline
\end{tabular}

Keterangan:

$\begin{array}{ll}\text { ST }(\text { Sangat Tinggi) } & =3,50<\overline{K G} \leq 4,00 \\ \mathrm{~T} \text { (Tinggi) } & =2,50<\overline{K G} \leq 3,50 \\ \mathrm{CT}(\text { Cukup Tinggi/Sedang) } & =1,50<\overline{K G} \leq 2,50 \\ \text { TT (Tidak Tinggi/Rendah) } & =0 \leq \overline{K G} \leq 1.50\end{array}$

Dari hasil analisis yang ditunjukkan pada tabel 3 dan berdasarkan kriteria yang ditetapkan pada metode penelitian, maka dapat disimpulkan bahwa penampilan guru dapat dipertahankan.

\subsubsection{Data Tes Hasil Belajar Siswa}

THB diberikan ke siswa untuk memperoleh informasi tentang penguasaan siswa terhadap materi yang telah diajarkan. Hasil analisis deskriptif secara kuantitatif penguasaan matematika setelah diberi tindakan pada THB dapat dilihat pada tabel berikut.

Tabel 4. Statistik Skor Hasil Belajar Matematika Siswa Kelas Va SD Inpres Karunrung Makassar

\begin{tabular}{cc}
\hline Variabel & Nilai Statistik \\
\hline Subjek Penelitian & 26 \\
\hline Skor Ideal & 100 \\
\hline Rata-rata & 75,69 \\
\hline Standar Deviasi & 12,43 \\
\hline Varians & 154,46 \\
\hline
\end{tabular}




\begin{tabular}{cc}
\hline Variabel & Nilai Statistik \\
\hline Rentang Skor & 39 \\
\hline Skor Maksimum & 96 \\
\hline Skor Minimum & 57 \\
\hline Jumlah Siswa yang Tuntas & 22 \\
\hline Jumlah Siswa yang Tidak Tuntas & 4 \\
\hline
\end{tabular}

Pada tabel 4, menunjukkan bahwa hasil belajar siswa kelas Va SD Inpres Karunrung terhadap pelajaran matematika diperoleh skor rata-rata 75,69 dari skor ideal 100 dengan standar deviasi 12,43. Skor minimum yang diperoleh siswa adalah 57 dan skor maksimum yang diperoleh siswa adalah 96 dengan rentang skor 39. Jika skor hasil belajar dikelompokkan dalam lima kategori, maka diperoleh tabel distribusi frekuensi.

Tabel 5. Distribusi Frekuensi dan Persentase Skor Hasil Belajar Matematika Siswa Kelas Va SD Inpres Karunrung Makassar pada Tes Hasil Belajar

\begin{tabular}{ccccc}
\hline No & Nilai & Kategori & Frekuensi & Persentase \\
\hline 1 & $0-54$ & Sangat Rendah & 0 & $0,00 \%$ \\
\hline 2 & $55-64$ & Rendah & 5 & $19,23 \%$ \\
\hline 3 & $65-79$ & Sedang & 11 & $42,31 \%$ \\
\hline 4 & $80-89$ & Tinggi & 5 & $19,23 \%$ \\
\hline 5 & $90-100$ & Sangat Tinggi & 5 & $19,23 \%$ \\
\hline
\end{tabular}

Tabel 5, menunjukkan bahwa banyaknya siswa yang tuntas belajar atau yang mencapai ketuntasan individu yaitu siswa yang memperoleh skor 62-100 sebanyak 21 orang dari 26 orang siswa atau sekitar 80,77\%. Jadi banyaknya siswa yang belum tuntas, yaitu siswa yang memperoleh skor $0-61$, sebanyak 5 orang dari 26 orang siswa atau sekitar 19,23\%. Data ini menunjukkan bahwa ketuntasan klasikal tercapai.

\subsubsection{Respon Siswa terhadap Kegiatan Pembelajaran Matematika}

Respon siswa terhadap kegiatan pembelajaran matematika yang menggunakan pendekatan kontekstual dengan strategi REACT ini berdasarkan angket yang diberikan ke siswa yaitu:

Respon siswa terhadap pelajaran matematika berbeda-beda, mulai yang merasa bahwa matematika itu menyenangkan, gampang-gampang susah, menantang, hingga merasa bahwa matematika sangat sulit. Dari 26 siswa, 20 siswa $(76,92 \%)$ diantaranya mengatakan pelajaran matematika itu gampang dan atau menyenangkan. Dari hasil angket juga diperoleh 6 dari $26(23,08 \%)$ siswa yang mengatakan matematika susahsusah gampang. Mereka akan lebih senang lagi belajar matematika jika mereka berhasil memahami materi yang disajikan dan menjawab soal-soal yang diberikan oleh guru.

Berdasarkan kriteria keefektifan yang telah dibahas pada metode penelitian, maka dapat disimpulkan bahwa perangkat pembelajaran matematika dengan menggunakan pendekatan kontekstual dengan strategi REACT bersifat efektif, dimana semua komponen keefektifan perangkat pembelajaran matematika terpenuhi dan komponen (4) yaitu ketuntasan klasikal yang menjadi syarat utama terpenuhi.

Selain itu, berdasarkan kriteria kepraktisan yang juga telah dibahas pada metode penelitian, maka dapat disimpulkan pula bahwa perangkat pembelajaran matematika berbasis kontekstual dengan strategi REACT bersifat praktis, dimana semua komponen kepraktisan perangkat pembelajaran matematika terpenuhi. 


\subsection{Pembahasan}

Berdasarkan hasil ujicoba perangkat pembelajaran yang meliputi rencana pelaksanaan pembelajaran (RPP), lembar kegiatan siswa (LKS), dan buku siswa (BS) diperoleh data hasil pengamatan aktivitas siswa, data hasil pengamatan aktivitas guru, data hasil pengamatan pengelolaan pembelajaran matematika berbasis kontekstual dengan strategi REACT, data hasil tes belajar siswa dan respon siswa terhadap kegiatan pembelajaran matematika berbasis kontekstual dengan strategi REACT. Hasil analisis masing-masing data sebagai berikut:

\subsubsection{Hasil Pengamatan Aktivitas Siswa}

Pada kategori pertama, yaitu memperhatikan informasi dan mencatat seperlunya mulai dari pertemuan pertama hingga pertemuan ketiga diperoleh persentase rata-rata $12,22 \%$. Dimana siswa yang melakukan aktivitas tersebut dari pertemuan pertama sampai pertemuan ketiga mengalami peningkatan.

Pada kategori kedua, yaitu membaca LKS, materi pelajaran atau buku siswa (BS) diperoleh persentase rata-rata siswa yang melakukan kegiatan tersebut dari pertemuan pertama hingga pertemuan ketiga sebesar 12,59\%. Dimana yang melakukan aktivitas tersebut dari pertemuan pertama sampai pertemuan kedua memiliki persentase $12,22 \%$ dan mengalami peningkatan pada hari ketiga menjadi 13,33\%. Sedangkan persentase rata-rata siswa yang aktif pada kategori ketiga yaitu aktif terlibat dalam tugas sebesar $23,33 \%$.

Untuk kategori keempat, yaitu aktif berdiskusi dengan teman, persentase rata-rata siswa yang melakukan aktivitas ini sebesar $17,41 \%$. Dimana jumlah siswa yang melakukan aktivitas ini mengalami peningkatan dari pertemuan pertama hingga pertemuan ketiga. Hal ini disebabkan karena masalah-masalah yang ada pada buku siswa (BS) dan lembar kegiatan siswa (LKS) berkaitan dengan kehidupan sehari-hari yang dapat diselesaikan dengan beberapa macam alternatif jawaban sehingga memungkinkan siswa bertukar pikiran dan berdiskusi dalam menyelesaikan masalah tersebut.

Pada kategori kelima, yaitu mencatat apa yang disampaikan teman/guru, persentase rata-rata siswa yang melakukan aktivitas ini sebesar $11,85 \%$. Aktivitas pada kategori ke enam, yaitu mengajukan pertanyaan kepada teman/guru diperoleh persentase rata-rata pada kategori ini sebesar 5,19\%. Dimana jumlah siswa yang melakukan aktivitas ini mengalami peningkatan dari pertemuan pertama hingga pertemuan ketiga. Hal ini disebabkan karena beberapa siswa masih belum yakin dengan jawaban yang mereka peroleh setelah mengerjakan soal yang ada pada lembar kegiatan siswa.

Pada kategori ketujuh, yaitu menjawab/menanggapi pertanyaan guru/teman di pertemuan pertama adalah $10 \%$ namun menurun pada pertemuan kedua menjadi $6,67 \%$. Aktivitas ini mulai meningkat kembali di pertemuan ketiga menjadi $7,78 \%$ sehingga diperoleh persentase rata-rata siswa sebesar $8,15 \%$. Hal ini disebabkan karena pada pertemuan pertama soal-soal yang diberikan relatif sederhana sedangkan pada pertemuan kedua siswa masih berusaha membedakan jarak sebenarnya dan jarak pada peta serta makna dari skala sebagai suatu perbandingan dan pada pertemuan ketiga siswa telah memahami makna dari skala beserta contoh-contohnya dalam kehidupan sehari-hari sehingga siswa lebih aktif pada aktivitas ini daripada pertemuan kedua. Aktivitas siswa pada kategori kedelapan, yaitu memberi bantuan penjelasan kepada teman yang membutuhkan, diperoleh persentase rata-rata sebesar 5,56\%. 
Pada kategori terakhir, yaitu kegiatan diluar tugas, misalnya tidak memperhatikan penjelasan guru, mengerjakan tugas mata pelajaran lain, dan aktivitas lain yang tidak berhubungan dengan kegiatan belajar mengajar seperti tidur, melamun, dan lain sebagainya, diperoleh persentase rata-rata sebesar 3,70\%.

Berdasarkan data persentase rata-rata aktivitas siswa dari tiga kali pertemuan diperoleh informasi bahwa siswa lebih aktif melakukan kegiatan pada kategori kedua, ketiga, dan keempat yaitu membaca LKS materi pelajaran atau buku siswa, aktif terlibat dalam tugas dan aktif berdiskusi dengan teman. Hal ini disebabkan karena siswa tertarik mengerjakan tugas pada materi perbandingan yang berkaitan dengan masalah-masalah dalam kehidupan sehari-hari. Selain itu, format buku siswa (BS) dan lembar kegiatan siswa (LKS) yang dibuat dilengkapi dengan soal beserta gambar-gambar sehingga membuat siswa menjadi tertarik dan termotivasi belajar. Selain itu diperoleh informasi keseluruhan kategori terpenuhi, sedangkan syaratnya bahwa aktivitas siswa tercapai 5 dari 9 kategori dengan 4 syarat utama interval toleransi harus terpenuhi, yakni kategori (3), (4), (5), dan (8). Artinya, kriteria pencapaian waktu ideal aktivitas siswa tercapai.

\subsubsection{Hasil Pengamatan Aktivitas Guru}

Pada kategori pertama, yaitu menginformasikan masalah yang harus dikerjakan bersama dalam kelompok mulai dari pertemuan pertama hingga pertemuan ketiga diperoleh persentase rata-rata $8,89 \%$. Kategori ini memenuhi kriteria batas toleransi pencapaian waktu ideal, dimana waktu ideal yang disediakan sekitar 5 menit.

Pada kategori kedua, yaitu meminta siswa mengerjakan tugas LKS dengan kerjasama dalam kelompok diperoleh persentase rata-rata sebesar 8,89\%. Sedangkan persentase rata-rata pada kategori ketiga yaitu memberi arahan agar siswa selalu berada dalam tugas kelompok sebesar 6,67\%.

Untuk kategori keempat, yaitu mengontrol/berkeliling memperhatikan kerja kelompok, persentase rata-rata aktivitas ini sebesar 24,45\%. Untuk kategori kelima, yaitu membimbing dan memberikan bantuan kepada siswa, persentase rata-rata aktivitas ini 26,67\% . Dari kedelapan kategori aktivitas guru, terlihat bahwa kategori keempat dan kelima ini memiliki persentase rata-rata terbesar nilainya. Hal ini disebabkan karena guru lebih sering mengontrol/berkeliling memperhatikan kerja kelompok kemudian memberi bantuan dalam aktivitas kelompok.

Aktivitas pada kategori keenam, yaitu mengajukan pertanyaan yang merangsang berpikir siswa (pertanyaan yang membuka wawasan) diperoleh persentase rata-rata sebesar 13,33\%. Aktivitas guru pada kategori ketujuh, yaitu memberi umpan balik, diperoleh persentase rata-rata sebesar $11,11 \%$. Pada kategori terakhir, yaitu kegiatan di luar tugas, misalnya duduk diam di kursi, membaca koran, keluar kelas, merokok, dan sebagainya diperoleh persentase rata-rata sebesar $0,00 \%$.

Berdasarkan data tersebut, diperoleh informasi keseluruhan kategori terpenuhi. Sedangkan syaratnya bahwa aktivitas guru tercapai 5 dari 8 kategori pada interval toleransi harus terpenuhi, yakni kategori (2), (4), (5), (6), dan (7). Artinya, kriteria pencapaian waktu ideal aktivitas guru tercapai

\subsubsection{Hasil Pengamatan Pengelolaan Pembelajaran Matematika Berbasis Kontekstual dengan Strategi REACT}

Dari hasil pengamatan tampak bahwa sebagian besar aspek dapat terlaksana dengan sangat baik.

Dari hasil pengamatan dan berdasarkan rata-rata total pengelolaan pembelajaran matematika berbasis kontekstual dengan strategi REACT diperoleh tingkat keterlaksanaan aspek-aspek pada pertemuan pertama hingga ketiga yaitu 3,53 atau 
berada dalam kategori "Sangat Tinggi" sehingga dapat dikatakan bahwa pengelolaan pembelajaran matematika berbasis kontekstual dengan strategi REACT terlaksana dengan baik.

\subsubsection{Hasil Belajar Siswa}

Tes hasil belajar (THB) diberikan kepada siswa untuk memperoleh informasi tentang penguasaan siswa terhadap materi yang telah diajarkan. Hasil belajar siswa kelas Va SD Inpres Karunrung Makassar terhadap pelajaran matematika diperoleh skor rata-rata 75,69 dari skor ideal 100 dengan standar deviasi 12,43. Skor minimum yang diperoleh siswa adalah 57 dan skor maksimum yang diperoleh siswa adalah 96 dengan rentang skor 39.

Data tersebut menunjukkan bahwa siswa memperoleh pemahaman yang baik terhadap materi yang disajikan dengan menggunakan pembelajaran matematika berbasis kontekstual dengan strategi REACT. Hal ini dapat dilihat bahwa banyaknya siswa yang tuntas belajar yaitu siswa yang memperoleh skor $62-100$ sebanyak 21 orang dari 26 orang siswa atau sekitar $80,77 \%$. Sedangkan siswa yang belum tuntas, yaitu siswa yang memperoleh skor $0-61$, sebanyak 5 orang dari 26 siswa atau sekitar $19,23 \%$.

\subsubsection{Respon Siswa terhadap Kegiatan Pembelajaran Matematika Berbasis Kontekstual dengan Strategi REACT}

Respon siswa terhadap kegiatan pembelajaran matematika berdasarkan angket yang diberikan pada siswa sebagai berikut:

(1) Respon siswa tentang pelajaran matematika berbasis kontekstual dengan strategi REACT

Sebagian besar siswa senang dengan pelajaran matematika. Karena materi yang diberikan berkaitan dengan masalah sehari-hari sehingga mereka merasa bahwa materinya mudah dipahami. Beberapa siswa juga menyatakan bahwa matematika itu kadang susah atau kadang mudah.

(2) Respon siswa tentang lembar kegiatan siswa (LKS) dan buku siswa (BS) berbasis kontekstual dengan strategi REACT

Pada umumnya siswa senang dengan LKS dan buku siswa (BS) yang digunakan. Beberapa siswa beralasan bahwa mereka senang dengan buku siswa (BS) dan LKS yang digunakan karena bahasa dan gambarnya sangat mudah dimengerti serta menarik. Selain itu, dilengkapi dengan soal-soal yang berkaitan dengan masalah sehari-hari. Namun demikian, beberapa siswa juga berpendapat bahwa ada beberapa soal yang digunakan dalam LKS atau buku siswa (BS) agak rumit, namun sebagian besar siswa tertarik dengan Buku siswa (BS) dan LKS yang digunakan.

(3) Respon siswa tentang pembelajaran matematika berbasis kontekstual dengan strategi REACT

Pada umumnya, siswa senang dengan cara guru mengajar yang menggunakan pembelajaran matematika berbasis berbasis kontekstual dengan strategi REACT dan dengan cara bekerja kelompok. Mereka senang mengerjakan tugas-tugas dalam LKS secara berkelompok karena mereka dapat bertukar pikiran dan berdiskusi sehingga membuat mereka cepat mengerti dengan materi yang disajikan.

Dari angket yang diberikan kepada 26 orang siswa terdapat 20 orang siswa yang memberikan respon positif yaitu sekitar 76,92\%. Hal ini menunjukkan 
bahwa pada umumnya siswa memberikan respon positif terhadap perangkat pembelajaran yang digunakan.

Adapun indikator-indikator yang digunakan untuk menentukan keefektifan perangkat pembelajaran, yaitu:

a. Aktivitas Siswa

Terdapat 5 dari 9 kategori terpenuhi dalam hasil pengamatan aktivitas siswa.

b. Aktivitas Guru

Terdapat 5 dari 8 kategori terpenuhi dalam hasil pengamatan aktivitas guru.

c. Pengelolaan Pembelajaran

Pengelolaan pembelajaran terlaksana dengan kategori sedang.

d. Hasil Belajar Siswa

Hasil belajar siswa berada pada kategori sedang.

e. Respon Siswa

Minimal 50\% siswa respon siswa positif.

Perangkat pembelajaran yang telah dikembangkan dikatakan efektif apabila memenuhi 3 dari 5 indikator tersebut, tetapi indikator 4 harus terpenuhi. Dan berdasarkan hasil penelitian diperoleh informasi bahwa semua indikator tersebut di atas terpenuhi. Oleh karena itu, perangkat pembelajaran matematika yang menggunakan pendekatan kontekstual dengan strategi REACT yang telah dikembangkan yaitu rencana pelaksanaan pembelajaran (RPP), lembar kegiatan siswa, dan buku siswa (BS) dinyatakan layak, praktis, dan efektif untuk digunakan.

\section{Kesimpulan}

Berdasarkan hasil analisis data dan pembahasan, maka dapat disimpulkan dari hasil ujicoba diketahui bahwa perangkat pembelajaran berbasis kontekstual dengan strategi REACT bersifat praktis dan efektif. Dengan menggunakan perangkat pembelajaran berbasis kontekstual dengan strategi REACT, siswa jadi lebih aktif dalam proses pembelajaran yakni kategori (3) dengan rata-rata persentase waktu adalah 23,33\% berada pada interval toleransi PWI yaitu 17,2-27,2, kategori (4) dengan rata-rata persentase waktu adalah $17,41 \%$ berada pada interval PWI yaitu 12,8 - 22,9, kategori (5) dengan rata-rata persentase waktu adalah 11,85\% berada pada interval PWI yaitu 3,9-13,9, dan kategori (8) dengan rata-rata persentase waktu adalah 5,56\% berada pada interval PWI yaitu 6,1-16,1. Guru dapat membimbing kelompok bekerja dan belajar yakni kategori (2) dengan rata-rata persentase waktu adalah $8,89 \%$ berada pada interval PWI yaitu 6,1 - 16,1, kategori (4) dengan rata-rata persentase waktu adalah $24,45 \%$ berada pada interval PWI yaitu 17,2 - 27,2, kategori (5) dengan rata-rata persentase waktu adalah $26,67 \%$ berada pada interval PWI yaitu 21,7-31,7, kategori (6) dengan rata-rata persentase waktu adalah 13,33\% berada pada interval PWI yaitu 6,1 - 16,1 , dan kategori (7) dengan rata-rata persentase waktu adalah $11,11 \%$ berada pada interval PWI yaitu $6,1-16,1$. Tingkat kemampuan guru dalam mengelola proses pembelajaran dengan pendekatan kontekstual dan strategi REACT termasuk dalam kategori sangat tinggi. Skor ratarata yang diperoleh siswa pada tes hasil belajar adalah 75,69 dari skor ideal 100 dengan standar deviasi 12,43. Dimana 21 dari 26 siswa atau 80,77\% memenuhi ketuntasan individu. Data ini menunjukkan bahwa ketuntasan klasikal tercapai. Pada umumnya siswa memberikan respons yang positif terhadap perangkat pembelajaran yang digunakan. 


\section{Daftar Pustaka}

Darwis, M. (2007). Model Pembelajaran Matematika yang Melibatkan Kecerdasan Emisonal. Surabaya: Program Pascasarjana Program Studi Pendidikan Matematika Universitas Negeri Surabaya. Tidak diterbitkan.

Johnson, E., B. (2007). Contextual Teaching and Learning: Menjadikan Kegiatan Belajar-Mengajar Mengasyikkan dan Bermakna. Bandung: Mizan Learning Center (MLC)

Komalasari, K. (2010). Pembelajaran Kontekstual: Konsep dan Aplikasi. Bandung: PT Refika Aditama

Rayhan. (2011). http://edmymatheducation.blogspot.com/2011/06/contextual-teachingand-learning-with.html. Di akses pada tanggal 01 Agustus 2011.

Trianto. (2010). Mendesain Model Pembelajaran Inovatif-Progresif. Jakarta: Kencana Prenada Media Grup. 